\title{
Membership
}

remains, while her description of the Roman bronze crowns, discovered at Cavenham, Suffolk, is of outstanding importance. In the publication of her scientific papers, always carefully and lucidly constructed, Miss Layard was greatly aided, in later years, by the artistic abilities of her companion and friend, Miss Outram, who produced many beautifully executed illustrations of the sites they had examined together. Miss Layard was brought up in the old school of archaeology which taught that man had originated in post-glacial times, and was limited in distribution and antiquity. But, when confronted with the great changes in opinion upon these matters, which the discoveries of recent years have brought about, she examined them with an open mind, and, if convinced of their truth, accepted them unflinchingly. This was strikingly shewn when the flint implements from below the Red Crag was first made known to the scientific world. The implications of this discovery were in direct opposition to all that she had been taught to believe as true-but, as one of a Committee appointed to examine critically the pre-Crag specimens, she joined with her colleagues in pronouncing in favour of the claim that the flints were indeed artifacts.

Miss Layard was President of the Prehistoric Society of East Anglia in 1922-23 (publishing numerous papers in its Proceedings), one of the first women elected Fellow of the Society of Antiquaries, a Vice-President of the Suffolk Institute of Archaeology and Natural History, a Fellow of the Linnean Society, and was officially associated with other learned bodies. Though not a native of East Anglia, Suffolk had been her adopted home for many years, and it was here, and in Ipswich, where most of her work was done. Miss Layard possessed nothing short of a flair for making discoveries in archaeology, and her fame will rest on these. In some cases, perhaps, her interpretations of what she found failed somewhat in sufficient breadth and accuracy, but it is seldom that the two virtues of discovery and interpretation are present at their best in one and the same person. Miss Layard was a generous donor of specimens to the Ipswich Museum, and, in her will, left to this institution the bulk of her varied collections. She was a deeply religious wornan and her beliefs found practical expression in her constant readiness to alleviate the lot of the poor and needy. Miss Layard will always be revered by archaeologists for her many and great discoveries, and for a long life of devoted study of all that relates to ancient man.

J. REID MOIR.

\section{H. H. Halls}

Amid the cares of a full business and political life H. H. H. managed to find time for research in Prehistory. Fired by the example of W. G. Clarke he became one of the founders and the first honorary treasurer of the Prehistoric Society of East Anglia, and it was largely due to his persistence and initiative that the infant society decided to publish ' Proceedings.'

From the first Halls found flint implements steadily, and adding by purchase he built up the fine collection which he presented to Norwich Castle Museum. He worked at first in his home area discovering a Cissbury site at Markshall. He shared with W. G. Clarke the finding of mesolithic flaking sites at Bowthorpe and Hellesdon, and a Cissbury site at Gt. Melton. With me he shared the discovery of the Acheulean gravels at Whitlingham, following this up by the recognition of similar gravels and implements with mammoth remains at Carrow.

His outstanding quality was his fearless honesty, coupled with the ability to see clearly the essentials of a problem. He was one of the first workers to insist that the field evidence was entirely opposed to the then orthodox opinion that palaeolithic man did not enter Norfolk till post-glacial times and his sturdy refusal to accept 'text book statements' unchecked by field work exercised a healthy influence on younger workers. 